\title{
Discussion Paper Moving into the Mainstream: Who Graduates from Secured Credit Card Programs?
}

Larry Santucci

Federal Reserve Bank of Philadelphia Consumer Finance Institute
DP 19-02

May 2019

https://doi.org/10.21799/frbp.dp.2019.02 


\title{
Moving into the Mainstream: Who Graduates from Secured Credit Card Programs?
}

\author{
Larry Santucci* \\ Consumer Finance Institute \\ Federal Reserve Bank of Philadelphia
}

May 2019

\begin{abstract}
Secured credit cards - credit cards whose limit is fully or partially collateralized by a bank deposit — are considered a gateway product to mainstream credit access. As consumers demonstrate good usage and repayment behavior, they may be offered the opportunity to graduate to an unsecured credit card. This paper uses anonymized account-level data to examine the prevalence of account graduation in the secured credit card market since 2012. Using a fixedeffects regression model, we identify a set of usage and repayment behaviors that are correlated with account graduation.
\end{abstract}

Keywords: credit cards, secured credit cards, account graduation

JEL Classification Numbers: D14, G21

* Federal Reserve Bank of Philadelphia, Ten Independence Mall, Philadelphia, PA 19106-1574; Email: larry.santucci@phil.frb.org. Thanks to Ian McGroarty for his excellent research assistance and to Tom Akana, Nathan Blascak, Julia Cheney, Bob Hunt, Lauren Lambie-Hanson, Slava Mikhed, Dubravka Ritter, Barry Scholnick, and Tom Stark for their suggestions.

Disclaimer: This Philadelphia Fed discussion paper represents preliminary research that is being circulated for discussion purposes. The views expressed in these papers are solely those of the author and do not necessarily reflect the views of the Federal Reserve Bank of Philadelphia or the Federal Reserve System. Nothing in the text should be construed as an endorsement of any organization or its products or services. No statements here should be treated as legal advice. Any errors or omissions are the responsibility of the author. Philadelphia Fed discussion papers are free to download at https:/philadelphiafed.org/consumer-finance-institute/publications. 


\section{Introduction}

Secured credit cards — credit cards whose limit is fully or partially collateralized by a bank deposit — are considered a gateway product to mainstream credit access. As the consumer demonstrates good usage and repayment behavior, she may be offered the opportunity to graduate to an unsecured credit card. This paper uses anonymized account-level data to examine the prevalence of account graduation in the secured credit card market. The data allow us to directly observe instances of account graduation as well as the usage and repayment behavior leading up to the graduation event. We compare the behavior of secured card graduates and nongraduates and identify a set of usage and payment behaviors that are correlated with account graduation.

In this paper, we establish a set of stylized facts about secured card account graduation. Highlights include the following:

- Secured card graduation rates have accelerated in recent years across all credit score groups as well as within the initially unscoreable consumer population. Twenty percent of accounts in the 2012 cohort graduated by age 61 (months), whereas 20 percent of accounts in the 2017 cohort had graduated by age 11 .

- The lower a consumer's credit score is at account opening, the less likely it is that he or she will graduate to an unsecured card within the next 24 months.

- Consumers lacking a credit score at account opening ("initially unscored”) are much more likely to graduate within 24 months than those with a score.

- Initially unscored secured card customers tend to enter the score distribution in the mid-600s. The median entry score for those who go on to graduate to an unsecured card is 687, while the median entry score for nongraduates is 634 .

- About 25 percent of initially unscored secured card customers who go on to graduate establish an initial credit score of 728 or higher and would be considered super-prime customers.

- Whether or not the individual graduates to an unsecured credit card, the median time for an initially unscored customer to establish a credit score from the opening of a secured card account is six months. 
- The consumer's most recent credit score has the largest effect on the probability of account graduation. Higher scores are associated with a higher likelihood of graduation and vice versa.

- Instances of account inactivity, delinquency of 30 or more days, or utilization over 80 percent are associated with lower graduation rates.

- Paying the full account balance each month is associated with a higher probability of graduation.

\section{Background}

Recent research has found that credit cards are the most common entry product into the credit markets (Brevoort and Kambara, 2017). About 38 percent of consumers begin their credit history with a credit card, followed by student loans (15.8 percent), and retail loans including department store credit cards (14.1 percent). Despite their prevalence among nascent credit users, credit cards remain inaccessible to many people. Credit card approval typically requires the consumer to have a credit history with enough tradelines and account activity to generate a reliable credit score. Moreover, the score must be high enough to pass lenders’ minimum underwriting standards. Thus, while the approval rate for consumers with a super-prime credit score (720 or greater) has remained above 80 percent since at least 2013, the approval rates for consumers with deep subprime scores (579 or less) and consumers without a credit score are below 20 percent (Consumer Financial Protection Bureau, 2017).

Many consumers who are unable to qualify for a traditional credit card turn to secured credit cards to fulfill their credit and payment needs. Secured credit cards work just like the familiar unsecured credit card, except that some portion of the credit limit (up to 100 percent) is secured by a deposit held at the card-issuing bank. By signing their credit card agreement, consumers grant the bank unilateral access to the funds and are prohibited from accessing the deposited funds for the duration of the credit relationship. The agreement grants the bank the right to withdraw the funds under certain circumstances, such as if the consumer defaults on his or her credit card debt. The key to the lender being able to approve low- or no-score consumers is the security deposit, combined with any monthly or annual fees, which offsets charged-off debt. 
There are several distinct subpopulations that are unable to be approved for traditional credit cards because either they lack a credit score or their score is not high enough to be approved by a mainstream issuer. Individuals who may not have a credit score include those new to the country, young adults, and one-time credit users who have been in a prolonged period of credit account inactivity. Consumers without a credit score are often considered "credit invisible.” An estimated 26 million Americans are credit invisible, while another 19 million are unscoreable because of insufficient or stale information (Brevoort, Grimm, and Kambara, 2015).

Secured card account holders who are meeting their credit obligations in a timely manner may eventually build a credit history that enables them to qualify for an unsecured credit card. The benefits of moving from a secured card to an unsecured card are numerous. Most important, the consumer is no longer required to maintain a security deposit with the issuing bank. When the secured credit card account is closed, the consumer's deposit is refunded, typically within 60 days. In addition, many unsecured credit cards have lower fees and interest charges, significantly higher credit limits, and more attractive rewards programs. ${ }^{1}$

Consumers who improve their credit score may also be targeted by outside lenders seeking to poach good customers from incumbent secured card issuers (Levy et al., 2016). While offers of unsecured credit cards can benefit the consumer, they can also be detrimental to the secured card lender, who may need to retain a secured card account holder for years to achieve a positive return (Levy et al., 2016). Attrition of well-performing secured card accounts to outside lenders also affects the secured lenders' portfolio by increasing the percentage of poorly performing secured card accounts relative to well-performing accounts. The portfolio with adverse selection will have higher credit losses than anticipated.

\section{A. Graduation Policy}

It is important for lenders to have a strategy in place to move high-performing customers to an unsecured credit card before the consumer is approved for an unsecured card at another lender. Industry professionals refer to the process of moving customers from a secured credit card to a fully unsecured credit card as the graduation policy (sometimes referred to as a strategy). According to one report, most - although not all — issuers of secured credit cards had graduation policies and processes in place by 2017 (CFPB, 2017). Graduation policies serve

\footnotetext{
${ }^{1}$ Santucci (2016) finds that secured credit cards generally offer less favorable pricing and features than unsecured cards.
} 
several important purposes. Graduation can increase account retention by making borrowers less vulnerable to poaching by outside lenders offering unsecured credit cards with more favorable terms. $^{2}$ As mentioned earlier, research suggests that banks may need to retain a secured card account holder for more than a year to achieve a positive return (Levy et al., 2016). Banks have an incentive to take advantage of information asymmetries by graduating good accounts before they can be poached. The possibility of graduating to an unsecured card may also provide an incentive for risky consumers to exert more effort and therefore share in the higher returns of an unsecured card account.

Secured card graduation may take one of several forms; however, in each case, the consumer's security deposit is fully refunded. ${ }^{3}$ A seamless graduation strategy would refund the consumer's security deposit and move the consumer from a secured to an unsecured card with no change in the account number or online account access. Depending on the bank's systems and capabilities, graduation may alternatively require closing the secured credit card account, refunding the security deposit, and opening a new unsecured credit card account under a different account number. In some cases, the consumer may also be required to reapply for the unsecured card. ${ }^{4}$ In contrast, issuers without graduation policies will close the secured card account and refund the customer's security deposit if the account is in good standing but will open an unsecured account for the customer only if he or she proactively makes a separate application for such a product.

While we cannot say what specific policies each secured credit card issuer uses to determine graduation eligibility and how those policies have varied over time, in this paper, we use a rich administrative data set to present an exposition of secured card graduation at the market level. The data allow us to identify secured credit card accounts at the point of origination

\footnotetext{
${ }^{2}$ The use of secured card graduation programs as a competitive tool to limit poaching is related to work by Drozd and Serrano-Padial (2012).

${ }^{3}$ Some issuers' graduation strategy includes an intermediate stage in which the account's credit limit is partially secured. This typically occurs not by releasing a portion of the security deposit but via an increase in the credit limit. For example, consumers with a $\$ 300$ credit limit secured by a $\$ 300$ security deposit may receive a limit increase to $\$ 500$ such that their account is now partially secured (60 percent). Our data do not allow us to distinguish between fully and partially secured credit cards. We do not address partially secured credit cards further.

${ }^{4}$ Some industry experts may not feel comfortable treating instances in which the consumer must apply for a new account, risking the possibility of not being approved, as a true graduation policy. In our data, which are described in detail in Section IV, we cannot distinguish between unsecured accounts opened with and without entering the reapplication process.
} 
and to track the accounts across time to closure, charge-off, or graduation. Using a fixed effects regression framework, we identify a set of consumer behaviors that are associated with graduation.

The secured credit card market has received little attention in the consumer finance literature, in part because of its small size relative to the broader credit card market. Secured credit cards accounted for roughly 5 percent of new general-purpose credit card accounts in 2016 (CFPB, 2017). There has been no theoretical work on account graduation with implications we could test. Nonetheless, the determinants of graduation should be closely related to the (logical) inverses of the determinants of default. Thus, we extrapolate from the literature on credit card default and delinquency risk to establish ex ante expectations for the sign and magnitude of regression coefficients. In the following section, we review the literature on secured credit cards and discuss selected results from the consumer credit default literature.

\section{Literature Review}

\section{A. Secured Credit Cards}

Santucci (2016) used administrative data to characterize the secured credit card market. Examining a snapshot of credit card accounts from December 2015, he found evidence of significant variation in pricing and features of secured credit cards compared with traditional, unsecured cards. For example, secured cards tend to require an annual fee, lack promotional offers and rewards programs, and have higher annual percentage rates (APRs) than unsecured cards. Santucci also found a great deal of variation in the characteristics of secured and unsecured card customers. The annual self-reported income of secured card customers is about 43 percent lower than that of unsecured card customers. There is also little overlap in the credit score distributions of secured and unsecured card customers at the time of account opening, conditional on having a credit score. While about 33 percent of consumers with an open secured card in December 2015 had a FICO score below 580 at the time of account origination, only 0.1 percent of customers with unsecured cards had a score below 580. Another study found that approximately half of all consumers who opened a secured card account in 2015 had no credit score (CFPB, 2017).

Santucci (2016) examined the extent to which consumers who open secured credit card accounts improve their credit score. While he was unable to determine whether responsible use 
of a secured card account in itself led to higher credit scores, his analysis found that keeping a secured card account open for at least two years was correlated with improved creditworthiness. At the median, maintaining an open secured card account for two years was associated with a 24point increase in credit score. On the other hand, closing the account before 24 months or having the account charged off by the lender was associated with 42-point and 60-point decreases, respectively.

In its latest biennial survey of the credit card market, the Consumer Financial Protection Bureau (CFPB) conducted a thorough examination of secured credit cards. Among the many findings in CFPB (2017), the report shares anecdotal evidence from several lenders that more than half of consumers who pass underwriting and ability-to-pay requirements ultimately do not fund their security deposit account. This is consistent with Santucci (2016) finding that the selfreported income distribution of secured card account holders is lower than that of unsecured account holders and may be indicative of consumers being severely budget constrained.

\section{B. Consumer Credit Default}

The credit card default literature is long and diverse. Here we highlight several important studies with results that can inform our analysis of secured card graduation. Greene (1992) constructed a model of credit card default (defined as six months without making a payment) using data from a well-known credit card company. He found that both the number of tradelines currently 30 days past due and the number of 30-day delinquencies within the past 12 months were associated with higher default rates. Sullivan and Worden (1995), examining charge-off rates at a large regional bank, found that consumers who had revolved a balance for at least nine of 12 months were more likely to charge off, as were those who were highly utilized (over 75 percent) or had used the cash advance feature on their credit card.

In a model of credit card delinquency (defined as 90 days past due) constructed with data from several credit card issuers, Gross and Souleles (2002) find that accounts with lower credit scores are more likely to default. Controlling for credit score, accounts with large balances or small payments were also more likely to default. Higher credit limits were associated with lower default rates as card issuers granted more credit to more creditworthy customers. Consistent with Gross and Souleles (2002), Agarwal and Liu (2003) find that credit scores and credit limits are negatively associated with 90-day delinquency and that account balance is positively correlated and significant. 


\section{Our Contribution}

This paper contributes to the literature on secured credit cards in two ways. First, it provides an empirical analysis of secured card graduation from a rich monthly administrative data source in which account graduation is explicitly reported. Thus, we needn't rely on matching algorithms or other probabilistic means to identify accounts that have graduated to unsecured cards. We present a series of stylized facts regarding aggregate secured card graduation rates across cohorts and credit score segments. We document significant changes that have occurred in the secured credit card market since 2012, the first year in which data were collected. Second, we estimate a model of account graduation with account-level fixed effects that helps us identify and characterize a set of consumer behaviors that contribute to account graduation. To our knowledge, this is the first and only paper to examine these topics.

\section{Data}

The primary source of data for this research is the Board of Governors of the Federal Reserve System's Capital Assessments and Stress Testing report (Y-14M). The Y-14M collects data on the loan portfolios of bank holding companies (BHCs) and intermediate holding companies (IHCs) with $\$ 50$ billion or more in total consolidated assets. ${ }^{5}$ The Federal Reserve implemented the Y-14M in June 2012 and collects monthly data on domestic first-lien closed-end 1- to 4family residential loans, home equity loans and lines, and credit card portfolios. The credit card data set captures a wide array of information on account type and statement activity as well as a limited amount of anonymized consumer information. Consumer data cannot be linked across banks, and we do not observe any demographic information such as occupation or employment status, marital status, race, or gender.

We selected a 11/2 percent random sample of secured general-purpose consumer credit card accounts from the largest secured card issuers reporting into the Y-14M. These issuers account for more than 95 percent of all secured credit cards in the Y-14M. Since our analysis is based on data from large BHCs and IHCs subject to Federal Reserve reporting requirements, our findings represent a very specific - albeit large — segment of the overall market. We cannot provide detail on cards issued by smaller banks, credit unions, or monoline issuers and are

\footnotetext{
${ }^{5}$ For more information about the FR Y-14M, refer to www.federalreserve.gov/apps/reportforms/reportdetail.aspx?sOoYJ+5BzDYnbIw+U9pka3sMtCMopzoV.
} 
unable to determine to what extent the findings presented herein are also representative of that market segment. ${ }^{6}$

The Y-14M is an unbalanced panel at both the bank and account levels. BHCs may have entered after June 2012 or exited prior to November 2018, the last month in the sample. In addition, IHCs were not required to comply with the Y-14M until December 31, 2016. New accounts enter the data set as they are originated and may exit for a variety of reasons, including account closure, portfolio sale, or reporting error.

\section{A. Data Cleaning}

Prior to analysis, we cleaned the data at the bank, customer, and account levels. At the bank level, we excluded accounts issued by banks that dropped out of the Y-14M during the sample period to avoid censored data. We also excluded banks that issued very few secured card accounts since the analysis will be conducted at the market level. At the customer level, we dropped customers identified by a nonunique customer identification number (customer ID). Most of these exclusions captured accounts with a null or zero customer ID.

Using this identifier, we retrieved data on all unsecured credit card accounts opened by our sample of secured card customers at the same bank. Thus, the full data set contains all account records on a monthly basis for any consumer in our sample who opened a secured credit card account between June 2012 and November 2018 at one of the secured credit card issuers in the Y-14M. Prior to data cleaning, the data set contained more than 92 million account-month records.

At the account level, each account is uniquely identified by the combination of bank and account identification numbers. According to the Y-14M instructions, the account number should uniquely identify each account and should remain the same from month to month, for the entire life of the account, regardless of whether a lost card is replaced or the account number is changed for any other reason. We dropped accounts that were contemporaneously associated with more than one account number. To ensure that our analysis captured the behavior of individual consumers, we excluded accounts with more than one authorized user. Next, we excluded secured card accounts with an origination date prior to the start of the bank's reporting into the Y-14M, since we did not have a complete set of records for these accounts. We also

\footnotetext{
${ }^{6}$ Monoline issuers specialize in a single type of financial service, such as consumer credit cards.
} 
excluded accounts with missing records, accounts that opened and closed in the same month, and accounts whose first record appeared prior to the origination date. Last, we excluded accounts associated with a mailing address outside of the 50 U.S. states.

\section{Account Graduation}

For each month an account is in the data set, we observe it in one of four distinct states: open and graduated, open and not graduated, closed by borrower, or closed by issuer. ${ }^{7}$ The graduation indicator variable, GRAD, is set equal to zero for all months in which a graduation does not occur and is equal to one if the account graduates from secured to unsecured that month. We right-censor records for accounts that are closed or graduated at the point at which such an event occurs.

\section{a. Treatment of New-Account Graduations}

We also observed many instances in the data in which a secured card account closed and an unsecured account opened in or around the month of account closure. These "new-account" graduations exist in a graduation gray area; we are uncertain whether they represent true secured card graduations in which the consumer is not required to reapply for credit, or whether they represent instances in which the consumer is offered the opportunity to apply for an unsecured card as part of the lender's customer retention strategy. New account graduations accounted for about 5 percent of all graduations identified in the data between June 2012 and November 2018. All but one of the banks in the sample reported some new account graduations alongside their same account graduations. Thus, the presence of new account graduations is not an artifact of a very different style of reporting. We also compared the average age of same and new account graduations by cohort year. New account graduations consistently occur sooner than same card accounts, although the gap has narrowed for recent vintages. On the basis of this information, we dropped these accounts from the analysis.

\section{B. Regression Data Set}

We also constructed a version of the analysis data set specifically for use in our econometric model, discussed in Section VI. For the regression, we selected a subsample of all secured credit cards opened between June 2012 and November 2016. To include more recent cohorts in the

\footnotetext{
${ }^{7}$ A fifth group consisted of accounts with records that ended abruptly with no indication of graduation or account closure. We treated such accounts as reporting anomalies and dropped them from the data set.
} 
analysis, we limit the performance window to the first 24 months after account origination. ${ }^{8}$ Over 80 percent of secured card accounts that graduate do so within the first 24 months. From this data set, we excluded accounts that were closed by the borrower prior to month 24 .

The decision to exclude borrower-closed accounts merits further discussion. It is unclear how such account closures should be interpreted. Had the borrower remained in the sample, she may have graduated. On the other hand, by closing her account, the consumer has precluded herself from graduating. In the results presented next, borrower-closed accounts are excluded from the data set. As a robustness check, we ran the baseline regressions including borrowerclosed accounts, coded as nongraduates. The coefficient estimates were remarkably similar in direction and magnitude (results not provided).

A full list of variables and their descriptions can be found in Table 1, followed by summary statistics for the entire regression sample in Table 2 and a means table calculated on the final observation of each account, split between graduates (GRAD =1) and nongraduates $($ GRAD $=0)$ in Table 3. We note that about 1.4 percent of all account-month records in the data set are coded as graduated, and approximately 20 percent of secured card account holders graduated to unsecured cards. We examine Table 3 in greater detail in the following section.

\section{Empirical Observations}

In this section, we establish a set of stylized facts about secured card graduation using data from the $\mathrm{Y}-14 \mathrm{M}$ as described in the previous section. We caution that these results come from a data set that, while large, represents the portfolios of a specific group of lenders and may not be representative of the entire secured credit card market. ${ }^{9}$

\section{A. Account Performance, Credit Scores, and Graduation}

As noted in Section III, there is no previous research to rely on when it comes to the determinants of secured card graduation, per se. We therefore rely on intuition as well as the

\footnotetext{
${ }^{8}$ Because no statement cycle ends during the same month as account origination, we do not count the account origination month toward the count of monthly observations. It is treated as a zero month, while the next monthly record is considered month one.

${ }^{9}$ As noted previously, the data are unbalanced at the bank level (as well as at the account level) since several banks entered after the June 2012 inception of Y-14M reporting. To understand their effects on our results, we compared the group of banks that reported credit card data over the entire sample period ("balanced bank panel”) with the entire set of banks. The balanced bank panel represents the majority of accounts in our sample, thus there is little difference between the two groups. For the remainder of the paper we use the full set of banks.
} 
literature on credit card delinquency and default to inform our expectations about the relationship between account performance, credit scores, and graduation. It seems reasonable to assume that the behaviors that determine secured card graduation might often be the opposite of the behaviors that determine credit risk. Our survey of the credit card default literature noted that delinquency, high balances (as a percentage of credit limit, known as credit limit utilization), small payments (relative to balance), and use of the cash advance feature are positively correlated with default. Thus, we expect that each of these behaviors should be negatively correlated with graduation. Since, in most cases, the point of opening a secured card is to establish or improve a credit score, we anticipate a positive relationship between credit score improvement and graduation. The findings of Gross and Souleles (2002) and Agarwal and Liu (2003) confirm an inverse relationship between credit scores and default rates, again suggesting a direct relationship between scores and graduation.

To the extent that building a credit score requires card usage (purchase and payment), periods of inactivity should be negatively correlated with graduation, and purchases followed by payment of balances should be positively correlated. Last, consumers with an existing relationship with the bank or consumers who have been granted a higher credit limit should be more likely to graduate, not only because of the preexisting relationship but also because the bank has additional data upon which to judge the consumer's creditworthiness.

Table 3 lends support to the previous conjectures. Account holders who graduate to an unsecured card are less likely to be delinquent, borrow cash, exceed 80 percent credit limit utilization, have periods of inactivity, or revolve a balance. Balutil_atd (balance as a percentage of credit limit, computed as a running mean) and cashutil_atd (cash balance as a percentage of cash limit, computed as a running mean) both tend to be lower for graduates, while purchutil_atd (purchases as a percentage of credit limit, computed as a running mean) tends to be higher. Likewise, graduates are more likely to make full payment on account balances.

Table 3 also shows that, on average, graduates exit the sample 4.8 months earlier than nongraduates. Graduates are more likely to have had an existing banking relationship with the secured card lender and, on average, fund a higher secured credit limit. ${ }^{10}$ At account origination,

\footnotetext{
${ }^{10}$ Anecdotal evidence suggests that, in most cases, consumers who are approved for a secured credit card are offered a credit limit that is higher than the limit they eventually collateralize. For example, a consumer may be approved for a $\$ 1,000$ credit limit but may choose to provide only $\$ 400$ in collateral.
} 
nongraduates are 30 percent less likely to have had a credit score than graduates (36 versus 66 percent, respectively). Nongraduates also tend to have very low initial credit scores; 50 percent of nongraduates had a score below 620 compared with 20 percent of graduates.

Upon exiting the sample (or reaching an account age of 24 months, whichever comes first), about 73 percent of nongraduates have a credit score below 620, whereas more than 90 percent of graduates have a credit score of 620 or higher. Ex post, few graduates or nongraduates lack a credit score, only 1 percent of graduates and about 6.4 percent of nongraduates.

\section{B. Cumulative Graduation Rates}

Cumulative graduation rates for secured cards indicate that many consumers with secured cards are indeed graduating to unsecured cards. Moreover, the rate at which those with secured cards are graduating has accelerated in recent years. Figure 1 plots the cumulative graduation rates for the 2012-2018 cohorts. By age 12 (months), 10.4 percent of accounts in the 2012 cohort (black line in Figure 1) had graduated to an unsecured card. By age 24, the percentage of graduates had increased to 16.7 percent. The graduation rate slowed considerably after age 24, taking more than 48 months to reach 20 percent. Table 4 displays the age at which each cohort reached graduation rates of $10,20,25$, and 30 percent. Twenty percent of accounts in the 2012 cohort graduated by age 61 . The graduation rate accelerated considerably for the 2013 cohort; 20 percent of accounts in the 2013 cohort had graduated by age 17, and 25 percent had graduated by age 54 .

In contrast, the 2014 cohort has yet to reach a 20 percent graduation rate. By age 48, the graduation rate stood at 15.8 percent (purple line in Figure 1). The rate of graduation in the 2015 cohort improved from 2014 but has not reached 25 percent.

Graduation has occurred much sooner for accounts in the 2016 and 2017 cohorts. Table 4 shows that, similar to the 2013 cohort, 20 percent of accounts in the 2016 cohort had graduated by age 17, and 25 percent had graduated by age 27. The 2017 cohort reached 20 percent by age 11 , and by age 13 , it had reached 30 percent. 


\section{Cohort Risk Composition}

Figure 2 displays the credit score distribution at account origination for the 2012-2018 cohorts. ${ }^{11}$ Over time, the share of accounts originated to consumers without a credit score or with a credit score of 620 or higher has fallen, while the share of accounts originated to consumers with scores below 620 has increased. Comparing the 2012 with the 2018 cohorts, the share of cards originated to customers in the 300-619 score range grew by 6.7 percent, with 2.6 percent coming from consumers with a credit score of 620 or more and the remaining 4.1 percent from the share of customers without a credit score at origination.

Figure 1 showed that the 2014 cohort experienced a much lower and slower graduation rate than previous or subsequent cohorts. In Figure 2, we see that the credit score distribution of accounts originated in 2014 was more heavily weighted toward consumers with a credit score, particularly those with very low scores. Compared with the 2013 cohort, the share of accounts originated to consumers with a score of 300 to 619 was 7.8 percent higher in the 2014 cohort, mostly because of a 7.3 percent reduction in the share of accounts originated to consumers without a credit score. As we will see in the next subsection, this shift away from unscored consumers to low-score consumers accounts for about 12 percent of the overall change in graduation rates.

\section{Two-Year Account Graduation Rates}

Figure 3 presents two-year graduation rates by cohort year and credit score at origination. ${ }^{12}$ Credit score at origination rank orders graduation rates within each cohort. In addition, consumers lacking a credit score at origination (MISS) are much more likely to graduate than those with a score. Compared with consumers with a score of 620 or higher (620p), consumers without a credit score at origination were on average 7.8 percent more likely to graduate by age 24.

Recall from Figure 1 that the overall graduation rate for the 2014 cohort was 11.8 percent, 10.2 percent lower than the 2013 cohort. Figure 3 shows that, in fact, two-year

\footnotetext{
11 The credit score distributions reported here closely mirror those reported in CFPB (2017), whose analysis is also based on data sampled from the Y-14M, as well as that reported by Feddis and Murphy (2017) and attributed to Argus Information and Advisory Services.

12 As of the writing of this report, the 2017 and 2018 cohorts had not reached 24 months and are excluded from Figure 3.
} 
graduation rates in the 2014 cohort were lower than the 2013 cohort across all credit score segments. In particular, the graduation rate for accounts in the MISS segment — which accounted for 39 percent of accounts originated — fell by about 40 percent, from 33.1 percent to 20 percent. But graduation rates were lower for all score segments; from the lowest score bin (300-549) to the highest score segment (620p), two-year graduation rates were lower by 43,49 , 47, and 41 percent, respectively, than in the 2013 cohort. Holding the credit score distribution constant, we find that changes in the graduation rate accounted for more than 88 percent of the total reduction in graduation rates from 2013 to 2014.

\section{E. Consumers Missing a Credit Score at Origination}

In subsection $\mathrm{D}$, we found that credit score at origination rank orders graduation rates within every cohort. In some sense, this result is mechanical; it should take less time to improve a 620 score to 660 than to improve a 300 score to 660. Figure 3 also demonstrated that consumers lacking a credit score at origination (MISS) are much more likely to graduate than those with a score. This result holds for every annual cohort in our sample and provides some evidence that the population of secured card customers is nonhomogeneous; the characteristics and outcomes of consumers without a credit score at the time of account origination differ from those of consumers with a low credit score.

Secured card customers without a credit score at the time of account opening tend to enter the score distribution with a score in the 600s. Table 5 displays the percentiles of initial credit scores for secured card account holders without a score at origination, overall and by graduation outcome. At the median, secured card graduates enter the score distribution at 687, while at the median, nongraduates enter at 634 . About 25 percent of initially unscored secured card customers who graduate establish an initial credit score of 728 or higher and would be considered super-prime customers. ${ }^{13}$ Whether or not the consumer graduates, the median time to establish a credit score from the opening of a secured credit card account is about six months. That is not to say that opening the secured card account is the only reason why the consumer became scoreable; consumers with a secured card may be simultaneously trying to improve their

\footnotetext{
${ }^{13}$ Consumers with credit scores of 720 or above are generally considered to be very low risk, or super-prime. See https://www.consumerfinance.gov/data-research/consumer-credit-trends/student-loans/borrower-risk-profiles/.
} 
score by other means, such as filing disputes with the credit bureaus over inaccurate information, paying off old debts, or opening other new credit accounts.

\section{Econometric Model}

In Section V, we noted that secured card graduation rates have increased since 2012 and are occurring earlier in the account life cycle. In this section, we use OLS to estimate the aggregate policy function for account graduation. We suspect that changes in graduation policy are affected by account performance such that the relationship suffers from endogeneity bias. ${ }^{14}$ Thus, our regression results should be interpreted as an exercise in identifying consumer behaviors and characteristics that are associated with secured card graduation rather than evidence of any causal relationship.

Our model of secured card graduation is the following:

$$
G R A D_{i, t}=\beta_{0}+\boldsymbol{\beta}^{\prime}{ }_{1} \boldsymbol{A G} \boldsymbol{E}_{i, t}+\boldsymbol{\beta}_{2}^{\prime} \boldsymbol{X}_{i, t}+\boldsymbol{\beta}^{\prime}{ }_{3} \boldsymbol{Z}_{i}+\varepsilon_{i, t}
$$

where $i=1, \ldots, N$ and $t=1, \ldots, 24$. The binary variable, GRAD $\operatorname{GR}_{i, t}$ indicates whether account $i$ graduated in month $t$. Thus, an account that graduates in month 9 has $\operatorname{GRAD}_{i, t}=0$ for months 1 through 8, GRAD ${ }_{i, 9}=1$ for month 9, and then exits the sample. As in Gross and Souleles (2002), the vector $\boldsymbol{A} \boldsymbol{G} \boldsymbol{E}_{i, t}$ is a fifth-order polynomial in account age, with age indicating the number of months that account $i$ has been open as of period $t$. The vector $\boldsymbol{X}_{i, t}$ includes a set of account performance variables that vary over time. These variables make up the bulk of our explanatory variable set and include measures of delinquency, utilization, payment in full, change of address, and credit score. The vector $\boldsymbol{Z}_{i}$ is composed of explanatory variables that do not change over time and include the cohort year, card issuing bank, original credit limit, original credit score quartile, and a dummy variable indicating whether the account holder had a pre-existing relationship with the bank.

\footnotetext{
${ }^{14}$ Because increasing graduation rates could be a result of improved consumer behavior, issuers relaxing their graduation policies (as a result of improved consumer behavior), or both, a causal exposition of the effects of consumer behavior on the likelihood of account graduation would need to account for endogenous issuer graduation policies. The same can be said for the observed acceleration in graduation rates. We also note that improving macroeconomic conditions may have encouraged issuers to accelerate graduation - independent of improvements in consumer behavior - since the risk of making a bad decision is lower in a low-default environment.
} 


\section{Estimation Results}

Our objective in estimating equation (1) is to establish a set of conditional correlations between consumer behavior and the outcome of account graduation. To do this, we examine the signs and statistical significance of regression coefficients estimated by a linear probability model.

Predicting graduation rates out of sample is beyond the scope of this paper, thus any concern that predicted graduation rates might lie outside the $[0,1]$ interval is of no concern. In addition, the linear probability model simplifies coefficient interpretation. ${ }^{15}$

We estimate the model using three different specifications. First, we estimate the linear probability model with robust standard errors including $\boldsymbol{Z}_{i}$, the set of time-invariant characteristics measured at account origination. We then run a regression with account-level fixed effects and clustered standard errors in place of $\boldsymbol{Z}_{i}$. This specification allows us to control for any unobserved heterogeneity that may exist between accounts that is not captured in the limited information we have on the consumer at account opening. The fixed effects specification also plays to the data's strengths since it contains a wide array of high-frequency time-variant behavioral variables. Introducing account-level fixed effects into the model can also be disadvantageous since the parameter estimates are based solely on the within-account variation over time (Allison, 2005).

In the third specification, we replace the latestscorebin_ variables with credit score residuals and squared residuals from a regression of latest credit score on all of the time-varying explanatory variables. Doing so enables us to isolate the portion of the consumer's credit score that is associated with his or her credit behavior outside of the secured credit card account and identify its effect on graduation. The drawback of this specification is that it requires us to drop records for accounts that do not yet have a credit score, since they cannot have residuals.

We present the results in Table 6, with the model without account-level fixed effects in column (1), the fixed effects model in column (2), and the fixed effects model with credit score residuals in column (3). Comparing Models 1 and 2, we observe that adding account-level fixed effects has a modest effect on model fit, with an adjusted R-squared of 0.0644 compared with

\footnotetext{
${ }^{15}$ We also ran a version of the baseline model in a discrete time logistic regression and the results are qualitatively the same.
} 
0.05036. ${ }^{16}$ Fixed effects reduce the magnitude of the age polynomial coefficients (age, age2, age3, age4, and age5) without changing direction. The coefficients on five of the six count variables (d30count, cashcount, util80count, inactivecount, and pifcount) have larger magnitudes, as does average balance utilization to-date (balutil_atd). The variables rvcount, cashutil_atd, and purchutil_atd are no longer statistically significant at 5 percent. The shift of explanatory focus from account age to account behavior suggests that the fixed effects specification has controlled for unobserved account-level heterogeneity that had been influencing the age estimates.

The degree to which the coefficient estimates vary between the two model specifications depends on the degree of between — versus within — account variation present in the explanatory variables (Allison, 2005). Table 7 displays the proportion of variation in each of the noncategorical explanatory variables that is between accounts. The age polynomial contains a high degree of between-account variation, as does rvcount. The utilization variables cashutil_atd and purchutil_atd have very little between-account variation but are not statistically significant in the fixed effects model, implying that, after controlling for account-level heterogeneity, their within-account variation is uncorrelated with graduation.

Replacing the latestscorebin_ variables with credit score residuals and squared residuals greatly improves model fit, increasing the adjusted R-squared from 0.05036 to 0.1217 . However, as noted earlier, this specification excludes accounts that do not yet have a credit score. For the remainder of the paper, we focus on the results of the fixed effects specification with credit score bins, presented in column (2) of Table 6. We return to Model 3 after a discussion of the effects of credit scores on account graduation.

\section{A. Account Age}

Despite containing a high proportion of between-account variation (as demonstrated in Table 7), the age polynomial is statistically significant and economically meaningful. The model detects a conditional relationship between account age and graduation that trends upward nonlinearly with three points of inflection (see Figure 5). The first inflection point is a global minimum at age 3. The conditional probability of graduation is increasing from age 3 until age 14, at which time it

\footnotetext{
${ }^{16}$ The difference in (unadjusted) R-squared values for models with and without fixed effects is statistically significant at 0.1 percent, whereas the difference in adjusted R-squared values is not statistically significant.
} 
declines until age 19 before increasing until age 24. Between ages 7 and 8 , the curve crosses the $\mathrm{x}$-axis, indicating that, all else equal, accounts become increasingly likely to graduate after seven months. Thus, accounts that are very short lived tend to die from poor performance, while eventually longer lived accounts demonstrate the usage and repayment behaviors necessary for graduation.

\section{B. Count Variables}

Of the six count variables in the regression, inactivecount has the largest effect, with a one unit increase in the number of months inactive decreasing the probability of graduation at time $t$ by 31 basis points. An additional month in which the account is 30 or more days past due (d30count) is associated with a 28 basis point reduction in the probability of graduation at time $t$. The same can be said for each additional month the account's utilization rate is above 80 percent (util80count). Each additional month an account has a cash balance (cashcount) is associated with a 5 basis point decrease in the probability of graduation at time $t$. The variable pifcount has a small but statistically significant and positive effect on graduation. Conditional on having a positive balance at month end, a one unit increase in the number of months in which the account holder pays his or her balance in full is associated with a 10 basis point increase in the probability of graduation at time $t$.

\section{Utilization Variables}

The effects of utilization and account activity variables suggest that the secured credit card customer walks a fine line between usage and overutilization. While it is clear that periods of inactivity are associated with a lower graduation rate — recall that a one unit increase in inactivecount is associated with a 31 basis point decrease in the probability of graduating heavy utilization of the credit limit is also associated with a lower likelihood of graduation. The coefficient on balutil_atd is statistically significant and negative, indicating that, at the low credit limits typically associated with secured credit cards, banks may prefer to graduate consumers who do not appear to be overly credit constrained. ${ }^{17}$ A 10 percent higher utilization rate in any period reduces the likelihood of graduation in that period by about 11 basis points.

\footnotetext{
${ }^{17}$ Please refer to Table 3 for variable definitions.
} 


\section{Recent Credit Score}

The account holder's most recent credit score is a statistically significant determinant of account graduation. ${ }^{18}$ Recall that the consumer's most recent credit score is mapped into one of five segments: four quintiles of credit scores and a segment for consumers without a score. In our regression results, the omitted category is the 300-569 score group. Relative to the omitted category, consumers whose most recently refreshed credit score was between 570 and 619 were 18 basis points less likely to graduate at time $t$, and consumers who did not have a credit score at the most recent refresh date were 3.1 percent less likely to graduate. Likewise, consumers without a credit score were about 2.6 percent less likely to graduate than consumers in the omitted category. Alternatively, consumers whose most recent credit score fell into the 620 to 659 range were 1.2 percent more likely to graduate at time $t$, and consumers with scores 660 or over were 3.4 percent more likely to graduate.

\section{E. Model with Credit Score Residuals}

In Model 3, we replace the latestscorebin_dummy variables with credit score residuals and squared residuals, both of which are statistically significant at 0.1 percent. The signs on the coefficients indicate a concave quadratic; the probability of graduation increases with residual credit score at a decreasing rate. Compared with Model 2, this model places less emphasis on the age polynomial, cash advance usage, and account inactivity and more emphasis on delinquency and utilization through larger negative coefficients on d30count, util80count, balutil_atd, and purchutil_atd. Given the important role that utilization and delinquency play in determining a consumer's credit score, it is not surprising that these variables have a greater effect on graduation when their effect on credit score is removed.

\section{Summary and Conclusion}

Using a detail-rich monthly administrative data source, we document significant changes that have occurred in the secured credit card market since 2012. We present a series of stylized facts regarding aggregate secured card graduation rates across cohorts and credit score segments. In

\footnotetext{
${ }^{18}$ We note that, during exploratory data analysis, we tested the significance of a variable that measured the change in credit score. One challenge in including such a variable is how to treat consumers who transition from no score to, say, a score of 580. Bivariate correlation and regression analysis revealed that the latest credit score was equally correlated to the graduation rate as the change in score and was statistically significant. Thus, we dropped the score change variable in favor of the account holder's latest credit score.
} 
addition, we estimate a model of account graduation with account-level fixed effects that helps us to identify and characterize a set of consumer behaviors that contribute to account graduation.

We find that the consumer's most recent credit score has the largest effect on the probability of account graduation. Higher credit scores are associated with a higher likelihood of graduation and vice versa. Since credit scores are a function of the consumer's behavior across all credit relationships as well as collections, public records, and credit inquiries, secured card account holders should pay careful attention to anything that might harm their score during the time in which the secured card account is open.

Examining various metrics of secured card usage and repayment performance, we find that paying the full account balance each month is associated with a higher probability of graduation, while instances of account inactivity, delinquency, and utilization over 80 percent are associated with lower graduation rates. More generally, a 10 percent higher utilization rate in any period reduces the likelihood of graduation in that period by about 11 basis points.

In the years following the Great Recession, U.S. banks, regulatory agencies, and consumer-advocacy groups began focusing on ways to help consumers improve their financial well-being. Recent studies suggest that, by requiring upfront collateral and reporting payment activity to credit bureaus, secured credit cards can play an important role in that process. This paper provides some insight into the discussion by providing an analysis of graduation activity among some of the largest credit card issuers. Graduation rates have increased in recent years, while the time required to graduate has decreased considerably. With good payment behavior across all credit relationships including a secured credit card, many subprime and unscoreable consumers are able to enter the mainstream credit markets. 


\section{References}

Agarwal, S., and C. Liu. (2003). " Determinants of Credit Card Delinquency and Bankruptcy: Macroeconomic Factors,” Journal of Economics and Finance 27(1).

Allison, P. D. (2005). "Fixed Effects Regression Methods for Longitudinal Data Using SAS,” Cary, NC. SAS Institute, Inc.

Brevoort, K., P. Grimm, and M. Kambara. (2015). “Credit Invisibles,” Consumer Financial Protection Bureau Data Point, 2015.

Brevoort, K., and M. Kambara. (2017). “Becoming Credit Visible,” Consumer Financial Protection Bureau Data Point, June 2017.

Consumer Financial Protection Bureau. (2017). “The Consumer Credit Card Market,” December 2017.

Drozd, L., and R. Serrano-Padial. (2012). “Dynamic Poaching in Credit Card Lending,” unpublished manuscript.

Feddis, N., and B. Murphy. (2017). "Re: Request for Information Regarding Consumer Credit Card Market, Docket No. CFPB-20017-0006” Letter to Monica Jackson, June 8.

Greene, W. H. (1992). “A Statistical Model for Credit Scoring,” NYU Working Paper EC-92-29.

Gross, D., and N. Souleles. (2002). “An Empirical Analysis of Personal Bankruptcy and Delinquency,” Review of Financial Studies 15(1).

Levy, R., L. Cummings, J. Hogarth, K. Asrow, and T. Ladha. (2016). "Secured Credit Cards: Innovating at the Intersection of Savings and Credit,” Center for Financial Services Innovation White Paper.

Santucci, L. (2016). “The Secured Credit Card Market,” Federal Reserve Bank of Philadelphia, Payment Cards Center Discussion Paper 16-03.

Sullivan, A. C., and D. Worden. (1995). “Credit Cards and the Option to Default,” George Fox University, Faculty Publications School of Business, Paper 39. 
Table 1. Definition of Model Variables

\begin{tabular}{|c|c|c|}
\hline & Variable & Description \\
\hline 1 & grad & $=1$ if account graduated to unsecured during month, 0 otherwise \\
\hline 2 & age & Account age in months \\
\hline 3 & d30count & $\begin{array}{l}\text { Number of months the account was reported } 30 \text { or more days delinquent to } \\
\text { date }\end{array}$ \\
\hline 4 & cashcount & Number of months the account had a cash balance to date \\
\hline 5 & util80ever & $\begin{array}{l}\text { Number of months the account's ending balance was greater than } 80 \% \text { of } \\
\text { credit limit to date }\end{array}$ \\
\hline 6 & inactivecount & $\begin{array}{l}\text { Number of months the account had no purchases, no ending balance, and } \\
\text { no payment due to date }\end{array}$ \\
\hline 7 & pifcount & $\begin{array}{l}\text { Number of months the ending account balance was paid in full to date, } \\
\text { conditional on having a positive balance }\end{array}$ \\
\hline 8 & rvcount & $\begin{array}{l}\text { Number of months the account holder paid less than the full balance but at } \\
\text { least as much as the minimum amount due }\end{array}$ \\
\hline 9 & balutil_atd & Statement ending balance, divided by credit limit, average to date \\
\hline 10 & purchutil_atd & $\begin{array}{l}\text { Purchases made during statement period, divided by credit limit, average to } \\
\text { date }\end{array}$ \\
\hline 11 & cashutil_atd & Statement ending cash balance, divided by credit limit, average to date \\
\hline 12 & latestscorebin & $\begin{array}{l}\text { Accountholder's most recent credit score value as reported by bank, } \\
\text { grouped into five bins: MISS, 300-569, 570-619, 620-659, and 660p. }\end{array}$ \\
\hline 13 & origlimit & Original credit limit \\
\hline 14 & relationship & $=1$ if accountholder had an existing relationship with the bank; 0 otherwise \\
\hline 15 & origscorebin & $\begin{array}{l}\text { Accountholder's credit score value at account origination as reported by } \\
\text { bank, grouped into five bins: MISS, 300-549, 550-579, 580-619, and } \\
620 \text { p. }\end{array}$ \\
\hline 16 & cohort & Cohort year, 2012 to 2016 \\
\hline
\end{tabular}


Table 2. Descriptive Statistics, Regression Data Set

\begin{tabular}{llrrrr}
\hline \multicolumn{1}{c}{ Variable } & N & Mean & Std. Dev. & Min. & Max. \\
\hline grad & 829,820 & 0.0138 & 0.1165 & 0 & 1 \\
age & 829,820 & 9.9034 & 6.7434 & 0 & 24 \\
d30count & 829,820 & 0.1331 & 0.5503 & 0 & 14 \\
cashcount & 829,820 & 0.7876 & 2.5092 & 0 & 24 \\
util80count & 829,820 & 3.6832 & 4.6773 & 0 & 24 \\
inactivecount & 829,820 & 0.6859 & 2.1436 & 0 & 24 \\
pifcount & 829,820 & 3.0426 & 3.5922 & 0 & 23 \\
rvcount & 829,820 & 3.9024 & 4.8387 & 0 & 24 \\
balutil_atd & 786,334 & 0.5324 & 0.3025 & -0.16 & 2.8 \\
purchutil_atd & 786,334 & 0.4123 & 0.3186 & 0 & 3.88 \\
cashutil_atd & 786,334 & 0.0287 & 0.1093 & 0 & 1.85
\end{tabular}




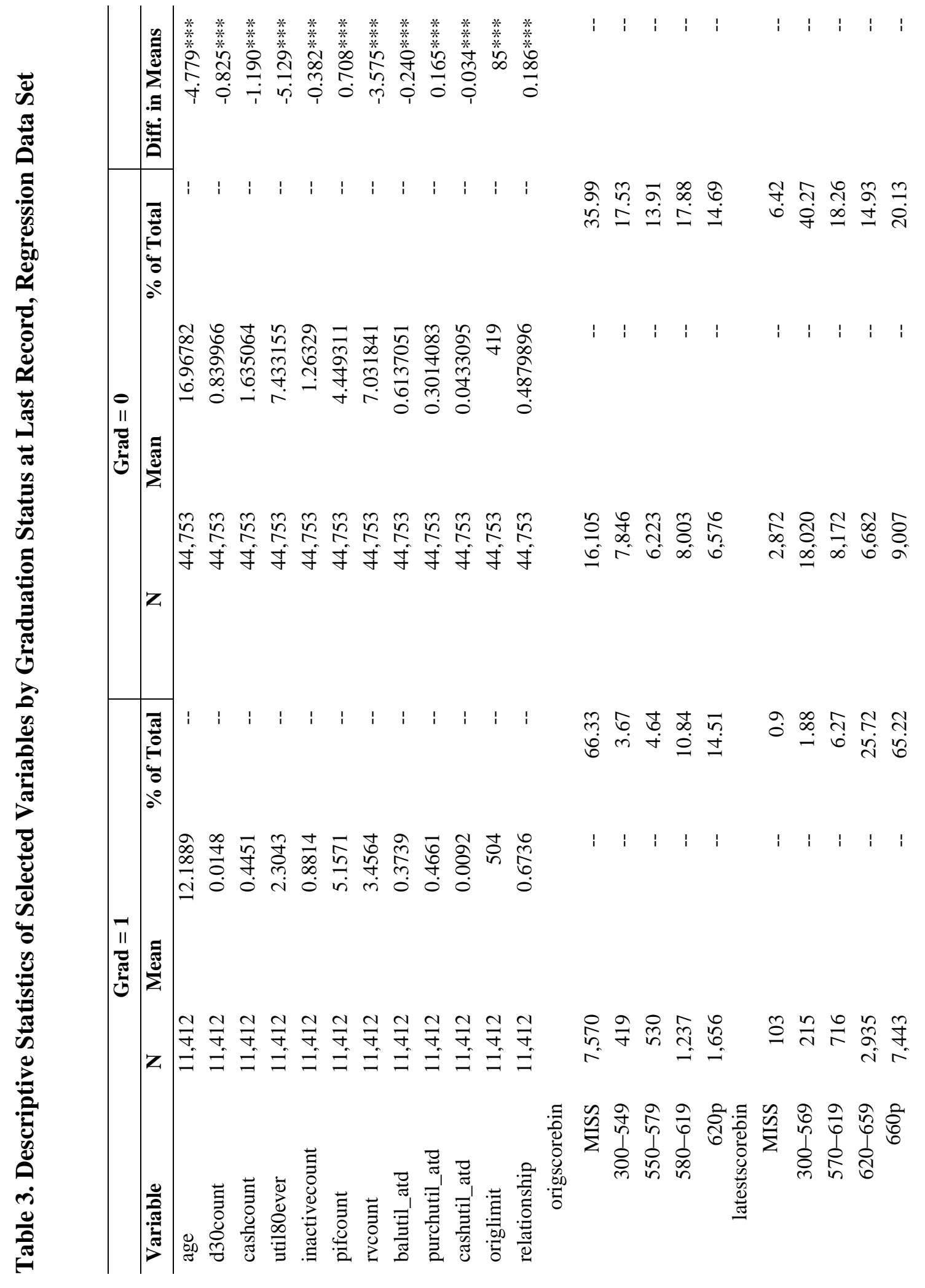

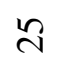




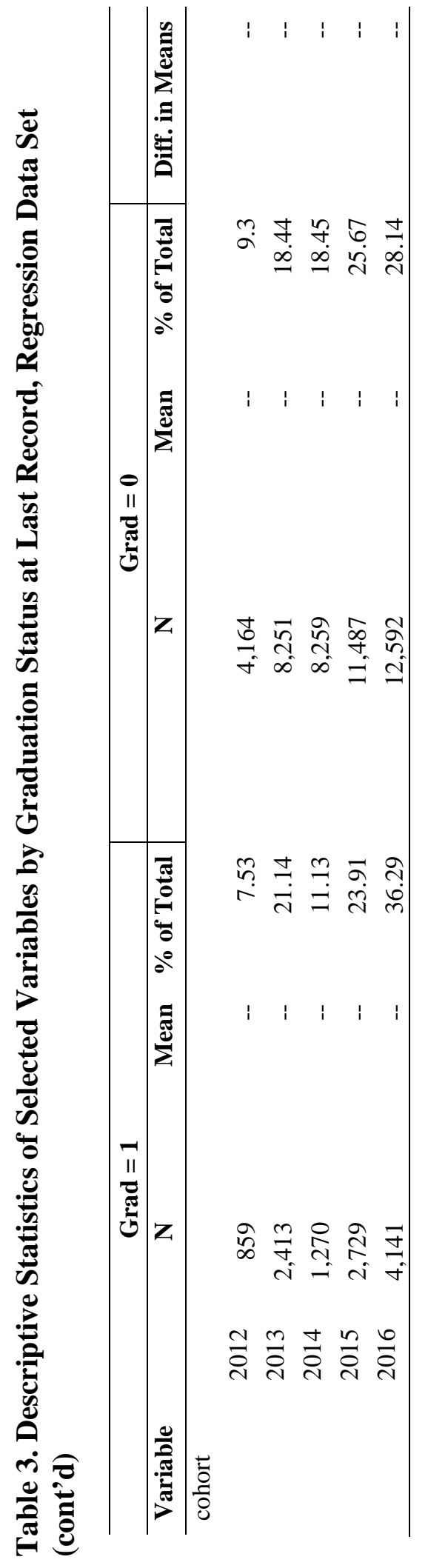


Figure 1. Cumulative Graduation Rates by Cohort Year

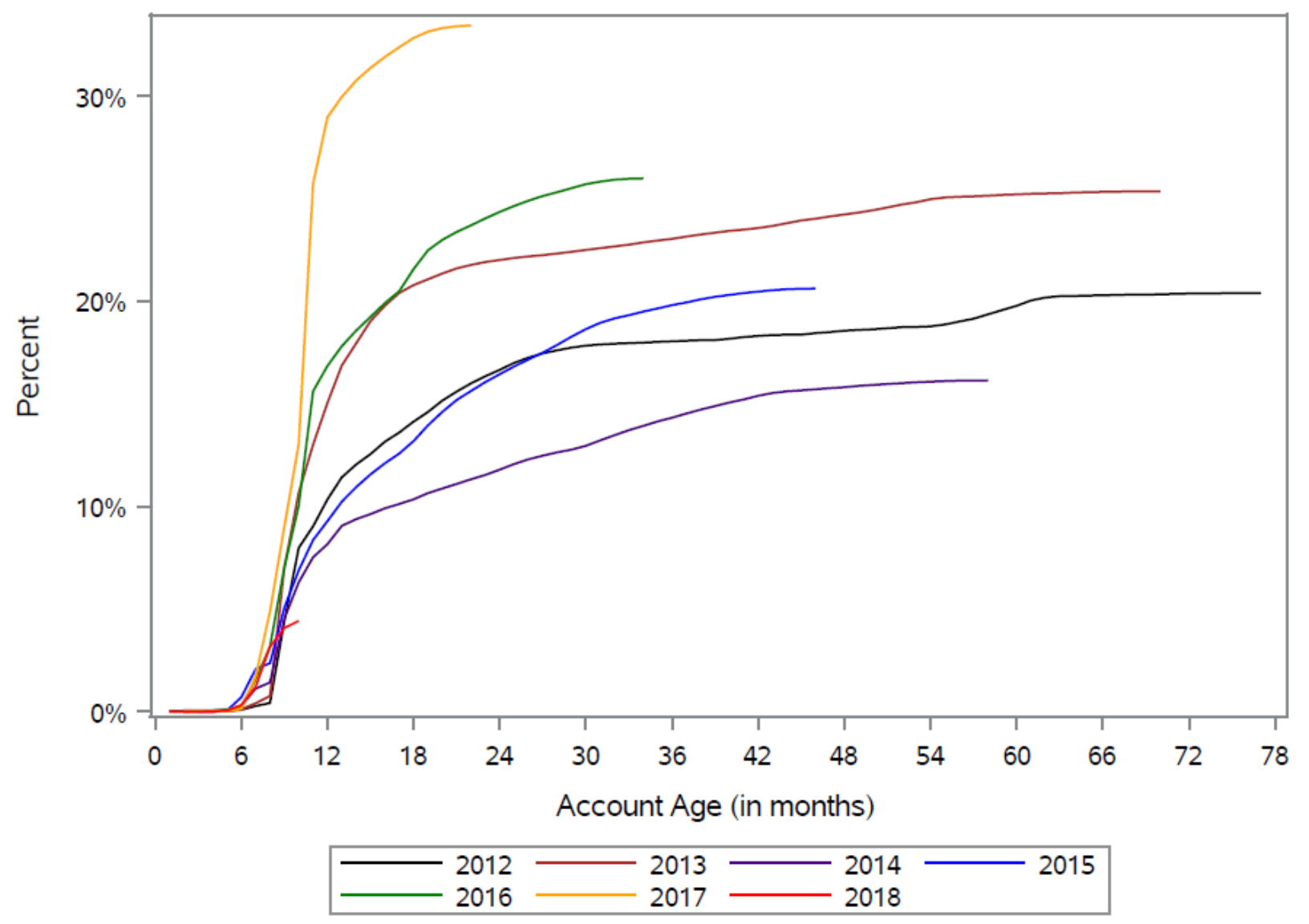

Source: Author's calculations using data contained in the FR Y-14M. 
Table 4. Age at Which Cohort Reached 10, 20, 25, and 30 Percent Graduation Rates

\begin{tabular}{crrrrrrr}
\hline Percent & \multicolumn{7}{c}{ Cohort Year } \\
Graduated & 2012 & 2013 & 2014 & 2015 & 2016 & 2017 & 2018 \\
\hline 10 & 12 & 10 & 17 & 13 & 10 & 10 & -- \\
20 & 61 & 17 & -- & 38 & 17 & 11 & - \\
25 & -- & 54 & -- & -- & 27 & 11 & - \\
30 & -- & -- & -- & -- & -- & 13 & - \\
\hline
\end{tabular}

Note: Account age is measured in months from account opening.

Source: Author's calculations using data contained in the FR Y-14M. 
Figure 2. Credit Score Distribution at Account Origination, by Cohort Year

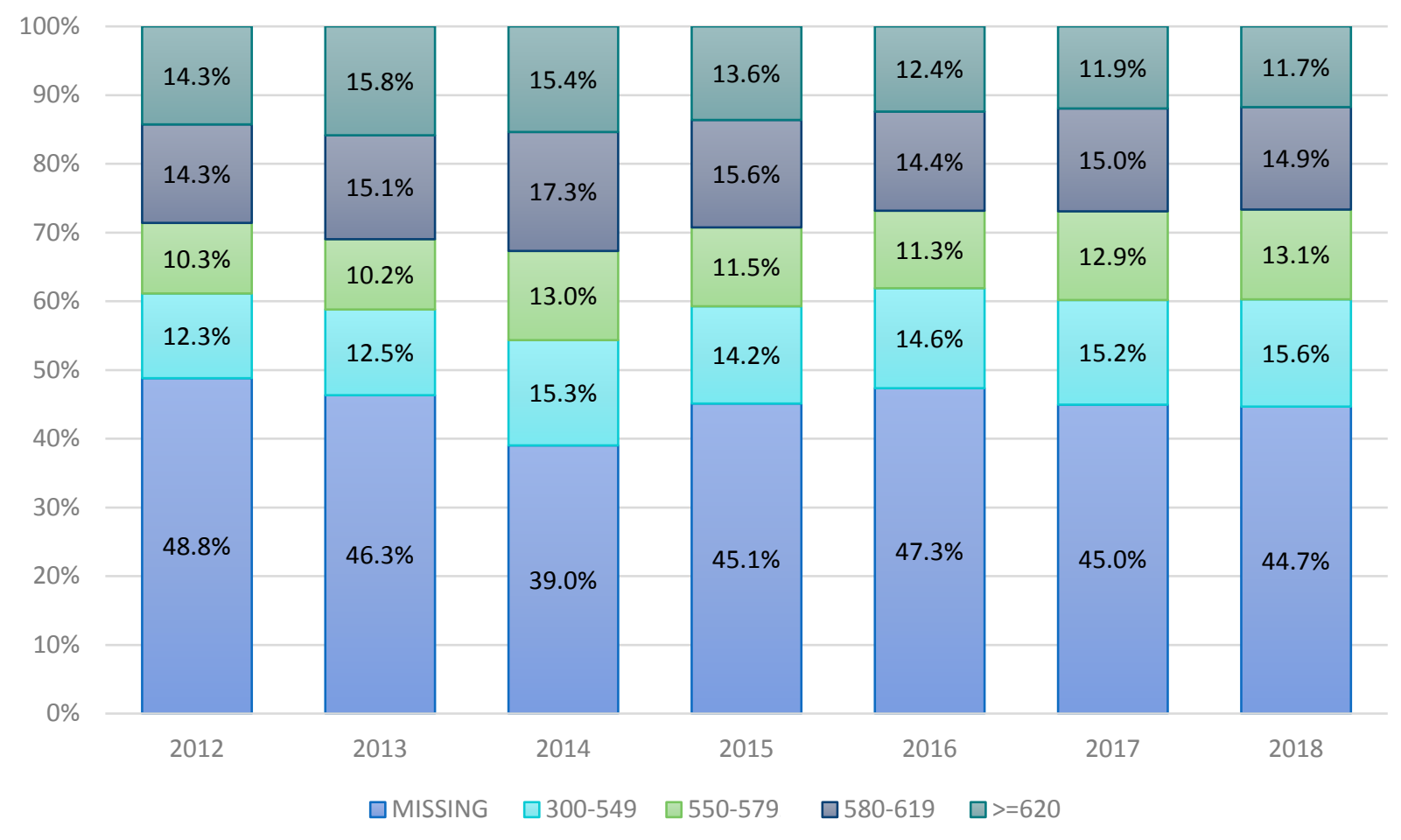

Source: Author's calculations using data contained in the FR Y-14M. 
Figure 3. Two-Year Account Graduation Rates by Cohort Year and Origination Credit Score Segment

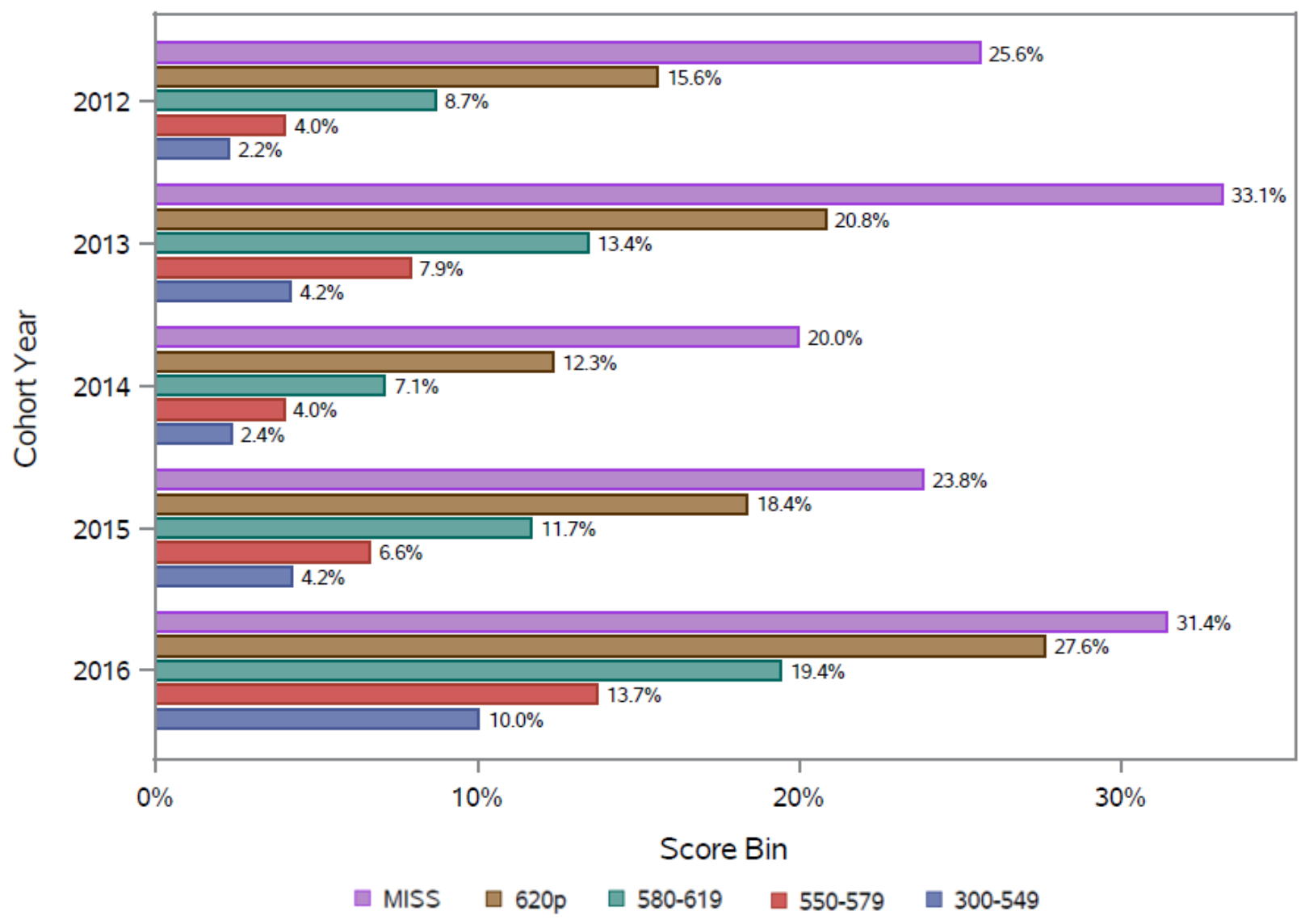

Source: Author's calculations using data contained in the FR Y-14M. 
Table 5. Selected Percentiles of First Credit Scores for Secured Card Account Holders Without a Credit Score at Origination, Overall and by Graduation Outcome

\begin{tabular}{rccr}
\hline Percentile & All & Grad = 1 & Grad = 0 \\
\hline 0th (min) & 304 & 304 & 304 \\
5th & 530 & 568 & 515 \\
10th & 560 & 597 & 544 \\
25th & 608 & 642 & 591 \\
50th & 659 & 687 & 639 \\
75th & 711 & 728 & 693 \\
90th & 750 & 757 & 740 \\
95th & 759 & 759 & 757 \\
100th (max) & 841 & 841 & 840
\end{tabular}

Note: Refreshed credit scores that were below 10 or equal to 999 were treated as missing. Source: Author's calculations using data contained in the FR Y-14M. 
Table 6. OLS Regressions

\begin{tabular}{|c|c|c|c|c|c|c|c|}
\hline Variables & $(1)$ & $(2)$ & (3) & Variables (cont'd) & $(1)$ & $(2)$ & (3) \\
\hline age & $\begin{array}{l}-0.02576 * * * \\
(0.00075)\end{array}$ & $\begin{array}{l}-0.02168 * * * \\
(0.00073)\end{array}$ & $\begin{array}{l}-0.02053^{* * * *} \\
(0.00082)\end{array}$ & origlimit & $\begin{array}{l}-0.000001444^{* * *} \\
(0.00000)\end{array}$ & & \\
\hline age2 & $\begin{array}{l}0.006713^{* * *} \\
(0.00022)\end{array}$ & $\begin{array}{l}0.005212^{* * *} \\
(0.00021)\end{array}$ & $\begin{array}{l}0.004214^{* * *} \\
(0.00023)\end{array}$ & relationship & $\begin{array}{l}-0.001777^{* * *} \\
(0.00039)\end{array}$ & & \\
\hline age3 & $\begin{array}{l}-0.0006068^{* * *} \\
(0.00002)\end{array}$ & $\begin{array}{l}-0.0003973^{* * *} \\
(0.00002)\end{array}$ & $\begin{array}{l}-0.0002388 * * * \\
(0.00003)\end{array}$ & latestscorebin_570_619 & $\begin{array}{l}-0.002353^{* * *} \\
(0.00019)\end{array}$ & $\begin{array}{l}-0.001816^{* * *} \\
(0.00025)\end{array}$ & \\
\hline age4 & $\begin{array}{l}0.00002256^{* * *} \\
(0.00000)\end{array}$ & $\begin{array}{l}0.00001186^{* * *} \\
(0.00000)\end{array}$ & $\begin{array}{l}0.000003257^{* * *} \\
(0.00000)\end{array}$ & latestscorebin_620_659 & $\begin{array}{l}0.01371^{* * *} \\
(0.00037)\end{array}$ & $\begin{array}{l}0.01223^{* * *} \\
(0.00050)\end{array}$ & \\
\hline age5 & $\begin{array}{l}-2.944 \mathrm{e}-07^{* * *} \\
(0.00000)\end{array}$ & $\begin{array}{l}-1.098 \mathrm{e}-07^{* * *} \\
(0.00000)\end{array}$ & $\begin{array}{l}4.447 \mathrm{e}-08^{* *} \\
(0.00000)\end{array}$ & latestscorebin_660p & $\begin{array}{l}0.03521^{* * *} \\
(0.00057)\end{array}$ & $\begin{array}{l}0.03404^{* * *} \\
(0.00083)\end{array}$ & \\
\hline d30 count & $\begin{array}{l}-0.001184^{* * *} \\
(0.00017)\end{array}$ & $\begin{array}{l}-0.002832^{* * *} \\
(0.00023)\end{array}$ & $\begin{array}{l}-0.003685^{* * *} \\
(0.00023)\end{array}$ & latestscorebin_MISS & $\begin{array}{l}-0.008262^{* * *} \\
(0.00041)\end{array}$ & $\begin{array}{l}-0.03125^{* * *} \\
(0.00093)\end{array}$ & \\
\hline cashcount & $\begin{array}{l}-0.0002887 * * * \\
(0.00005)\end{array}$ & $\begin{array}{l}-0.0005181^{* * *} \\
(0.00008)\end{array}$ & $\begin{array}{l}-0.0004793^{* * *} \\
(0.00008)\end{array}$ & origscorebin_550_579 & $\begin{array}{l}-0.001525^{* * *} \\
(0.00028)\end{array}$ & & \\
\hline util80count & $\begin{array}{l}-0.0008619^{* * *} \\
(0.00005)\end{array}$ & $\begin{array}{l}-0.002764^{* * *} \\
(0.00009)\end{array}$ & $\begin{array}{l}-0.003355^{* * *} \\
(0.00009)\end{array}$ & origscorebin_580_619 & $\begin{array}{l}-0.004513^{* * *} \\
(0.00031)\end{array}$ & & \\
\hline inactivecount & $\begin{array}{l}-0.001378^{* * *} \\
(0.00011)\end{array}$ & $\begin{array}{l}-0.003083^{* * *} \\
(0.00020)\end{array}$ & $\begin{array}{l}-0.001837 * * * \\
(0.00021)\end{array}$ & origscorebin_620p & $\begin{array}{l}-0.01327^{* * *} \\
(0.00044)\end{array}$ & & \\
\hline pifcount & $\begin{array}{l}0.0006817^{* * *} \\
(0.00012)\end{array}$ & $\begin{array}{l}0.001048^{* * *} \\
(0.00020)\end{array}$ & $\begin{array}{l}0.001223^{\text {*** }} \\
(0.00021)\end{array}$ & origscorebin_MISS & $\begin{array}{l}0.0008304 * * \\
(0.00041)\end{array}$ & & \\
\hline rvcount & $\begin{array}{l}0.0007040^{* * *} \\
(0.00009)\end{array}$ & $\begin{array}{c}-0.000006827 \\
(0.00017)\end{array}$ & $\begin{array}{c}-0.0002407 \\
(0.00017)\end{array}$ & cohort 2013 & $\begin{array}{l}0.006081^{\text {*** }} \\
(0.00054)\end{array}$ & & \\
\hline balutil_atd & $\begin{array}{l}-0.009938^{* * *} \\
(0.00056)\end{array}$ & $\begin{array}{l}-0.01066^{* * *} \\
(0.00115)\end{array}$ & $\begin{array}{l}-0.01503^{* * *} \\
(0.00123)\end{array}$ & cohort 2014 & $\begin{array}{l}0.005034^{* * *} \\
(0.00048)\end{array}$ & & \\
\hline purchutil_atd & $\begin{array}{l}0.01021^{* * * *} \\
(0.00056)\end{array}$ & $\begin{array}{l}0.001682 * \\
(0.00092)\end{array}$ & $\begin{array}{l}-0.007979 * * * \\
(0.00101)\end{array}$ & cohort 2015 & $\begin{array}{l}0.0009891^{* *} \\
(0.00048)\end{array}$ & & \\
\hline \multirow[t]{7}{*}{ cashutil_atd } & $\begin{array}{l}0.004778^{* * *} \\
(0.00085)\end{array}$ & $\begin{array}{l}-0.001442 \\
(0.00224)\end{array}$ & $\begin{array}{l}-0.003082 \\
(0.00235)\end{array}$ & cohort 2016 & $\begin{array}{l}0.003484^{* * *} \\
(0.00047)\end{array}$ & & \\
\hline & & & & score_resids1 & & & $\begin{array}{l}0.00007203^{* * *} \\
(0.00001)\end{array}$ \\
\hline & & & & score_resids2 & & & $\begin{array}{l}-1.396 \mathrm{e}-07^{* * *} \\
(0.00000)\end{array}$ \\
\hline & & & & constant & $\begin{array}{l}0.04881^{* * *} \\
(0.00113)\end{array}$ & $\begin{array}{l}0.02023^{\text {**** }} \\
(0.00095)\end{array}$ & $\begin{array}{l}0.03207 * * * \\
(0.00107)\end{array}$ \\
\hline & & & & $\mathrm{N}$ & 786,334 & 786,334 & 707,260 \\
\hline & & & & R Squared & 0.05040 & 0.119 & 0.177 \\
\hline & & & & Adjusted R Squared & 0.05036 & 0.0644 & 0.1217 \\
\hline
\end{tabular}

${ }^{*} \mathrm{p}<0.10, * * \mathrm{p}<0.05, * * * \mathrm{p}<0.01$

Notes: Robust SEs used. Model 1 includes bank-level fixed effects (suppressed to preserve anonymity). Model 2 replaces time invariant explanatory variables, including bank-level fixed effects, with account-level fixed effects. Model 3 also includes account-level fixed effects but adds residuals and squared residuals from a regression of latest credit score on all time-varying explanatory variables in place of the latestscorebin_ variables. 
Table 7. Proportion of Variation That Is Between Accounts for Noncategorical Predictor Variables

\begin{tabular}{lr}
\hline Variable & \multicolumn{2}{c}{$\begin{array}{c}\text { Proportion of Variation } \\
\text { Between Accounts }\end{array}$} \\
\hline age & 0.2342 \\
age2 & 0.9334 \\
age3 & 0.8755 \\
age4 & $--*$ \\
age5 & 0.2987 \\
d30count & 0.0148 \\
cashcount & 0.0018 \\
util80count & 0.1679 \\
inactivecount & 0.0214 \\
pifcount & 0.0785 \\
rvcount & 0.2918 \\
balutil_atd & 0.0059 \\
purchutil_atd & 0.0064 \\
cashutil_atd & 0.0027
\end{tabular}

Notes: To compute the proportion of variation that is between accounts, we regress each explanatory variable on the account-level fixed effects dummy variables with robust standard errors and compute the squared correlation between $\bar{x}_{i} \hat{\beta}$ and $\bar{y}_{i}$. A * indicates that the proportion could not be calculated.

Source: Author's calculations using data contained in the FR Y-14M. 
Figure 5. Conditional Probability of Graduation as a Function of Age Polynomial, in Basis Points

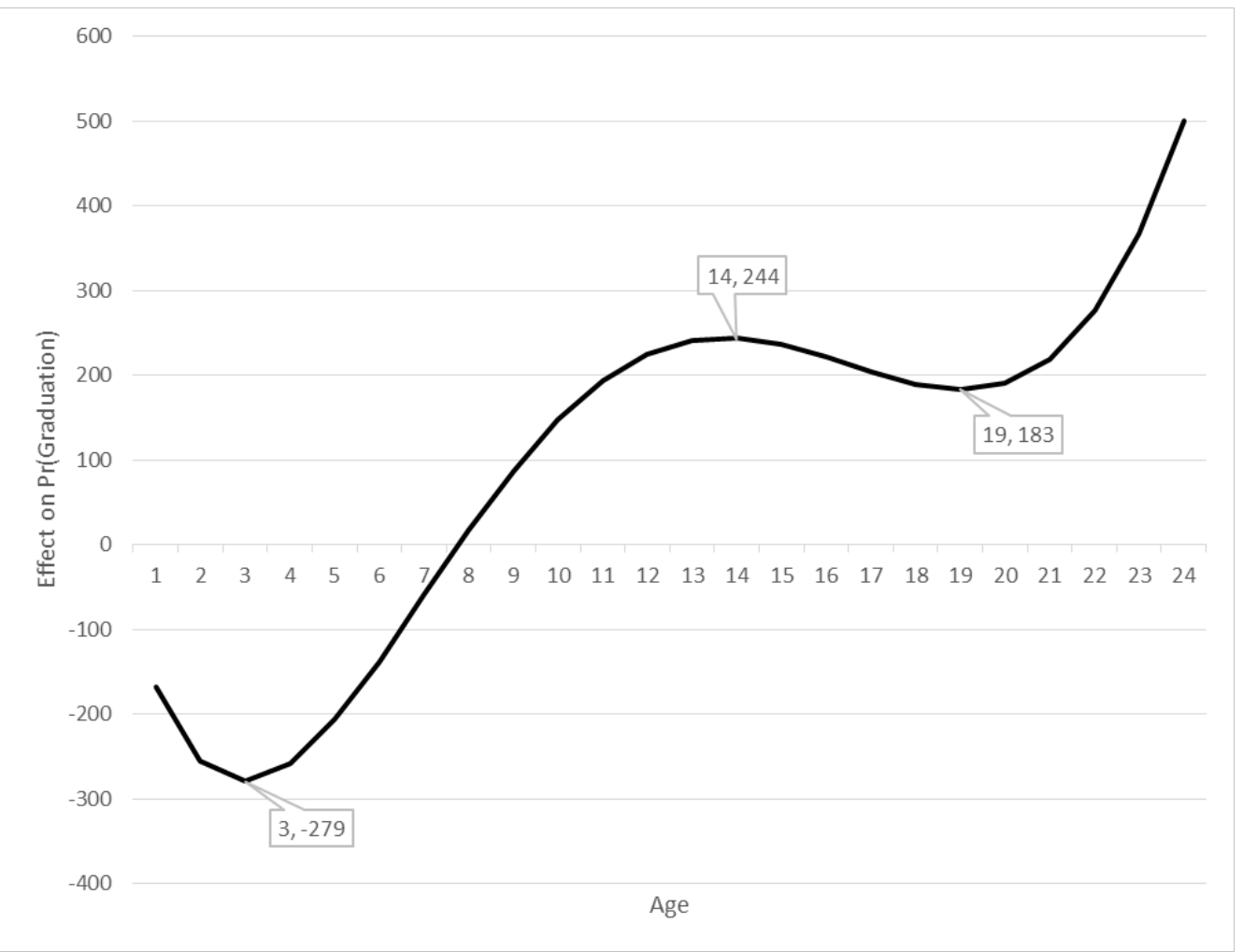

Note: The curve is a fifth-order polynomial in account age with coefficients estimated in a fixed-effects regression model. Coefficient estimates can be found in column (2) of Table 6. The unit of measure is basis points. Inflection points are called out.

Source: Author's calculations using data contained in the FR Y-14M. 


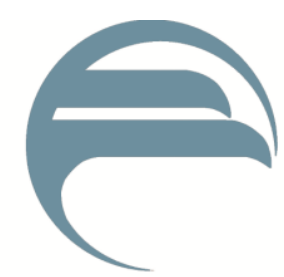

FEDERAL Reserve BANK of PHILADELPHiA

Consumer Finance Institute Discussion Paper Series

http://www.philadelphiafed.org/consumer-finance-institute 